\title{
INTEROPERABILITY: HOW TO IMPROVE THE MANAGEMENT OF PUBLIC FINANCIAL RESOURCES
}

\author{
Györgyi Nyikos, Bálint Szablics and Tamás Laposa ${ }^{1}$
}

DOI: $10.24989 /$ ocg.v331.36

\section{Abstract}

The article deals with the application of interoperable digital solutions in the domain of public financial management in order to improve the effectiveness of administrative procedures.

The practical relevance of the topic is derived from the Digital Single Market Strategy for Europe which promotes the interconnection of public portals to elevate the added value of the digitisation of public services. The interconnection of portals and electronic registers can notably facilitate the reduction of administrative burdens, foment the creation of new digital services and contribute to the creation of the Digital State. Nonetheless, there has been little research on how it works in practice and on its impact on the efficiency of public financial management.

The paper systematically reviews the main concepts of public financial management and the relevant strategies on the interoperability of public services. Based on this, it aims to analyse a series of Hungarian practices on interoperability to identify success factors that could support the design of new digital solutions to improve the management of public financial resources.

Keywords: interoperability, public financial management, e-government, public data

\section{Introduction}

Public financial management (PFM) determines the way governments treat public revenues and expenditures and their medium-to-long-term impacts. These procedures and the functions of public financial management are backed by various information systems and their utilization has shown an exponentially growing tendency in the past two decades. There is an abundant literature on the evaluation and comparison of these systems, which are frequently categorized according to main functions, types of service provider or as to the modernity of the applied technology.

The new digital technologies are transforming our society and economy and are opening up new opportunities in the field of PFM as well to improve public services and make a better use of the available public data. In this transformation process, the connectivity of information systems and their capabilities to exchange data (interoperability) plays a crucial role.

This paper has three main aims. First, to review the institutional, legal and technological background of PFM in Hungary; second, to highlight the most relevant issues of interoperability; third, to analyse national PFM information systems from the perspective of interoperability and draw conclusions for their future development.

\footnotetext{
${ }^{1}$ All National University of Public Service, Budapest
} 


\section{Public finance management in Hungary}

Public Financial Management relates to the way governments manage public resources (both revenue and expenditure) and the immediate and medium-to-long-term impact of such resources. PFM systems are embedded in broader sets of processes, systems and institutions as depicted by Figure 1.

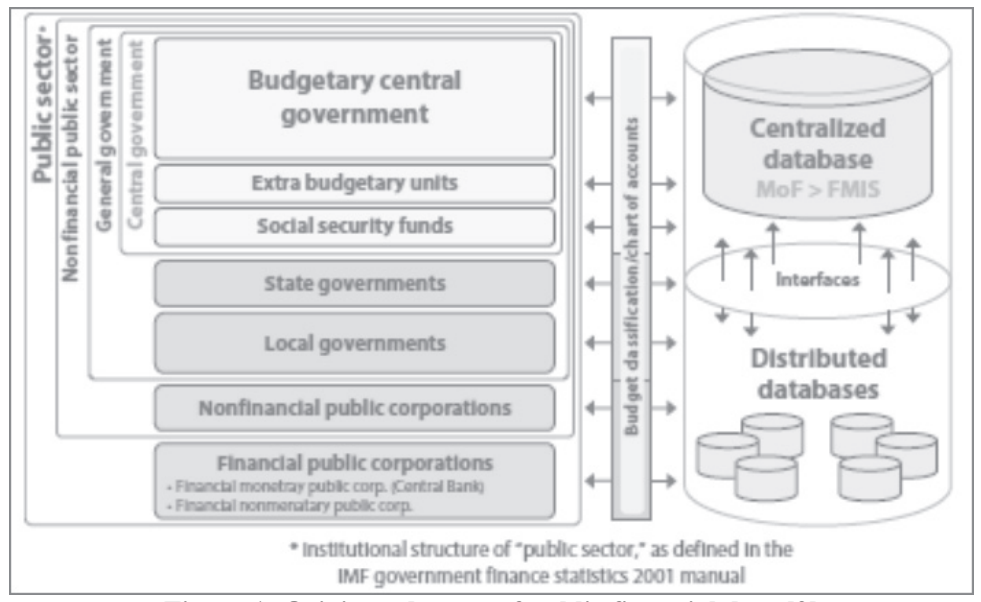

Figure 1: Origin and scope of public financial data [3]

PFM systems are deeply studied and monitored by the World Bank Group (WBG) mainly with respect to its aids and operations in developing countries. WBG and other international organizations finance several projects aiming at the development of PFM systems to increase the efficiency and effectiveness of the use of public sources. Not only the financed countries are in focus, but WBG also keeps track of other nations' activities on this field [23]. Moreover professionals have worked out an evaluation scheme in order to make these systems comparable and published their experiences in PFM development [16].

Analysis of different systems led to a grouping of functions [13]. The eight functional groups represent various fields of public administration not equally supported by integrated IT solutions. It is clear that state revenues and liquidity are two key elements of financing public expenditures, thus it is not surprising that Treasury System Account Management Systems (TSA) and Tax/Customs Management Information Systems (Cust MIS; Tax MIS) were the first to spread. From the late 2000's the penetration of Financial Management Information Systems (FMIS) gradually took the lead $^{2}$. The spread and evolution of PFM systems is shown by Figure 2-3.

\footnotetext{
${ }^{2}$ Consider the fact that by this time internet penetration reached $40 \%$ in developed countries according to ITU.
} 


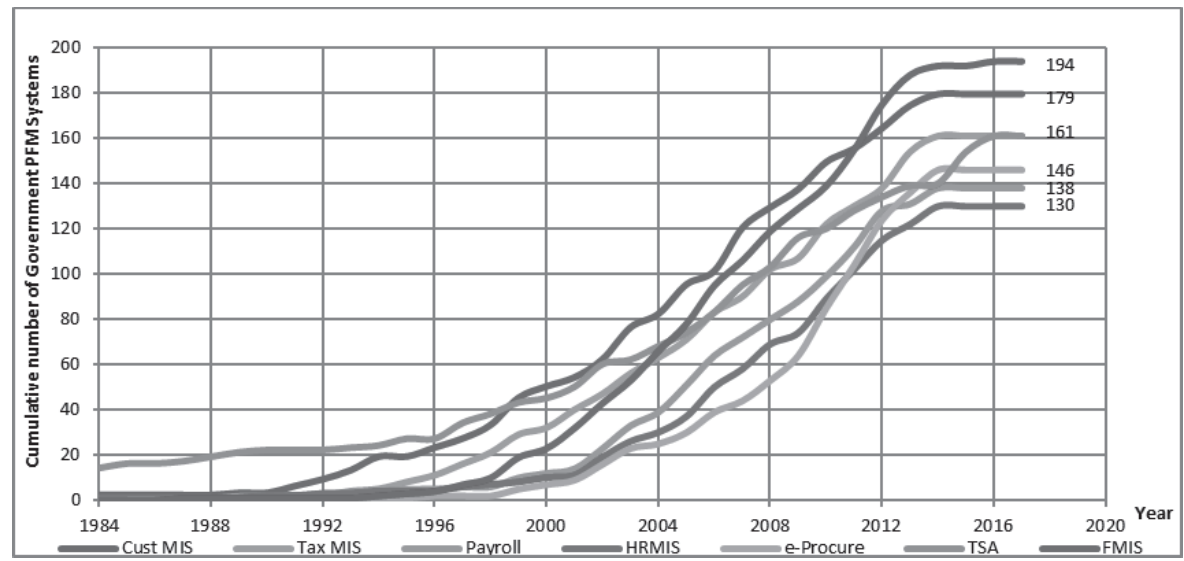

Figure 2: Services of PFM systems [22]

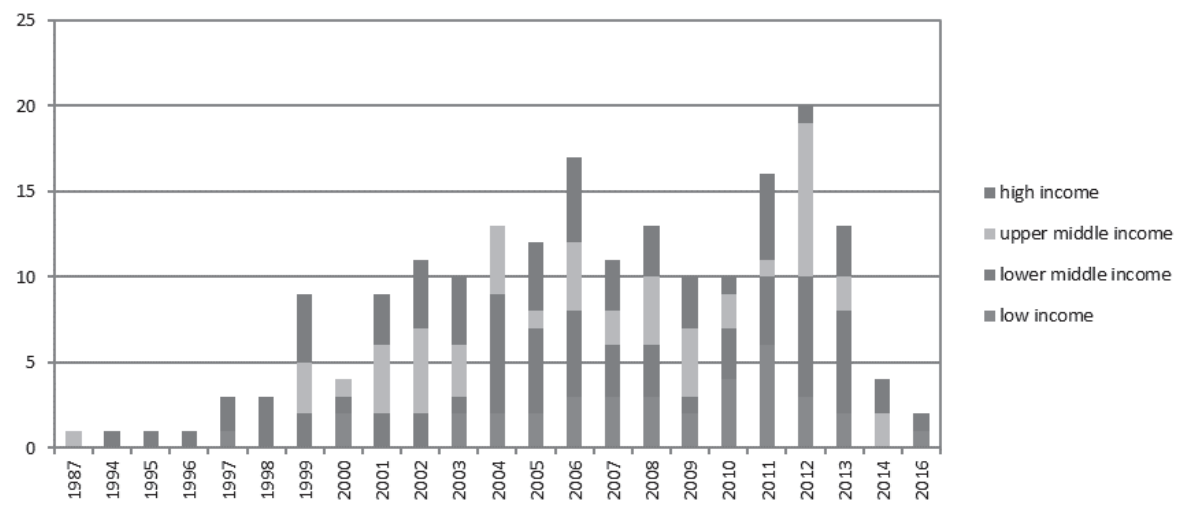

Figure 3: Year of implementation of FMIS solution in use vs. category of GNI per capita [22]

In another study researchers reveal [4] that usage of off-the-shelf systems is proportionally similar to the application of usually older and locally developed ones even if new solutions give a complex answer to governments' needs.

Among the various functions of FMISs, the topmost purpose is to cover all relevant procedures and the provision of a timely database to give a crutch to fiscal and other policy- and decision-makers. Budgetary cycle starts with budget preparation that constitutes the aggregate numbers of a law (or other legislative act) on state budget. The breakdown is made by the Spending Units (SPU), which is applicable for the execution of the budget and the calculation of cash-flows and the definition of other financial needs of the government.

Budgetary management requires a complex information system in view of the following factors: the large number of SPUs; the frequent modifications made within the budgetary year; market impacts on nominal revenue; the overlap of cycles of different budgetary years. Thanks to modern IT solutions and the spread of new technologies, it is becoming easier to tackle all these factors at the same time. A robust and integrated software provides the most suitable solution to meet all these 
needs. Nevertheless the WBG and other similar projects' experience show that such developments can take 6-7 years [4].

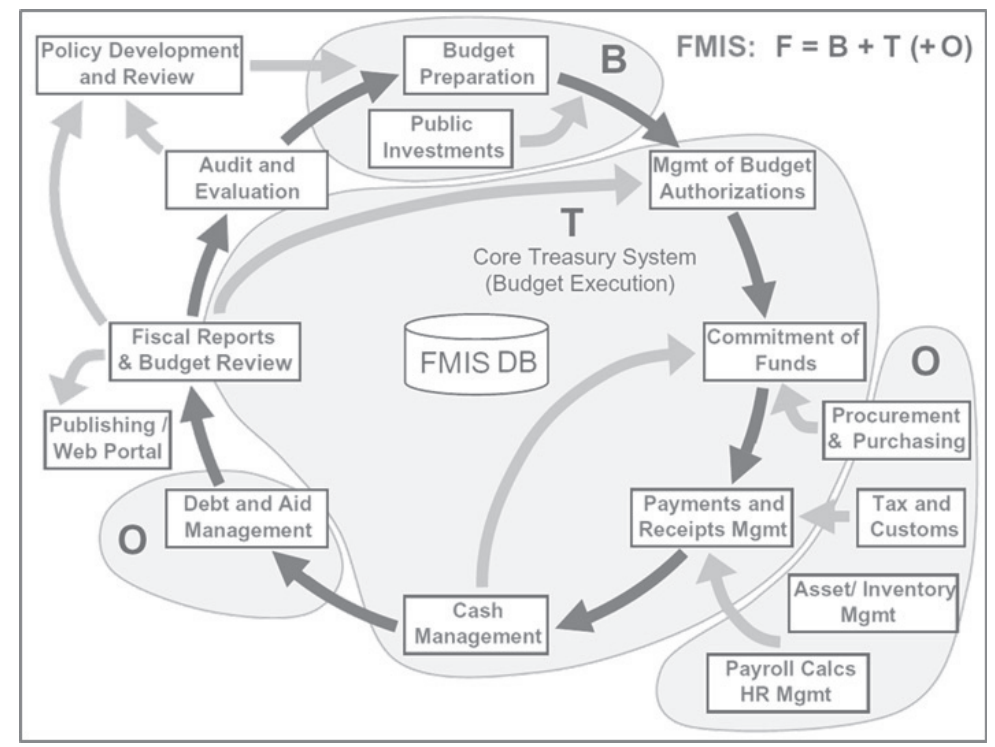

Figure 4: A modular approach for building FMIS [4]

According to the above research, there are modular systems (Figure 4) which originate from the business sector and are adapted to public finance specialities (e.g. Oracle, SAP). Although these solutions have an extended world-wide advisory network and they are perfectly fit for a business environment, they mainly focus on manufacturing and not the specificities of public financial management. In the latter decades a few new-wave answers emerged on the market (e.g. Freebalance, Unit4) focusing on the financial sector and or merely on public financial management. Although these off-the-shelf software can be tempting as they promise to be ready for use with a little bit of fine tuning, this can also be a pitfall as the accurate planning cannot be carried out without a good understanding of current and future procedures. This situation recalls the legendary reply of Euclid to King Ptolemy: 'there is no Royal Road'. As a consequence, research shows that governments are reluctant to change the current systems used for PFM even though new technologies may offer great progress in terms of efficiency.

\section{Relevant issues of interoperability}

New digital technologies ${ }^{3}$ are transforming our society and economy and are opening up new opportunities for public administrations as well. With these technologies it is possible to gather, manage, distribute and analyse data in order to improve efficiency and develop new services. In line with the recent technical developments, countries are digitising their public administrations to save time, reduce costs, increase transparency, and improve both data quality and the delivery of public services. There is still a great potential to further improve public services through end-to-end integration and automation, making better use of reliable sources of information and openly

${ }^{3}$ cloud computing, big data, artificial intelligence and the Internet of Things (IoT) 
publishing public data while ensuring that citizens' and businesses' records are treated in accordance with data protection rules to increase trust and confidence. Data is at the heart of all new technologies. However, data management is not entirely a technical issue; data access, transfer and liability are more difficult and less mature topics that deserve further assessment.

To achieve the possible results using the new digital technologies there are several EU policy initiatives in place, such as:

- $\quad$ the Digitising European Industry (DEI) policy package that included the European Cloud initiative [6] aiming to deploy a high capacity cloud solution for storing, sharing and re-using scientific data;

- $\quad$ the revision of the European Interoperability Framework [7], which aims to improve digital collaboration between public administrations in Europe and will benefit directly from the free flow of data;

- $\quad$ the EU's commitment to an open Internet [5]

The so called PSI directive [10] was created to provide a legal framework for the commercial utilisation of public sector information. The re-use of public sector data has been proven to increase economic growth and creates a large number of jobs in the SME sector. The directive harmonised the different rules and practices in member states and sought to avert the barriers represented by charges and different data formats to bringing out the full economic potential of public sector data.

On the other hand the relatively new General Data Protection Regulation (GDPR) provides a single set of rules for the entire EU, ensuring a high level of protection of personal data. Public sector entities processing personal data must comply with these rules as well. It is important to notice that GDPR prohibits restrictions on the free movement of personal data within the Union where these are based on reasons connected with the protection of personal data [13].

In this transformation process interoperability is an essential prerequisite for a competitive wellfunctioning digital system. It allows administrative entities to electronically exchange information in ways that are understood by all sides. It contains different aspects that impact on the delivery of digital public services, including:

- $\quad$ organizational interoperability ensuring the formalization of the processes (modelling) and the interoperability of the models and the harmonisation of administrative systems (i.e. it has several normative elements). Interoperability at organizational level prefers multilateral solutions for everyone instead of bilateral solutions;

- $\quad$ functional interoperability meaning the ability of systems to exchange data with each other where the provider issues data that can be interpreted;

- $\quad$ semantic interoperability ensuring the use of common descriptions of exchanged data;

- technical interoperability ensuring the introduction of necessary information systems environment to allow an uninterrupted flow of bits and bytes (technologies, standards, policies); 
- legal interoperability ensuring that legislation does not impose unjustified barriers to the reuse of data in different policy areas, guarantees the regulatory background where the cooperating organizations have the appropriate legal power to implement the data exchange in line with common standards. Since public administration can only perform an interoperability act after ex-ante legislation is in place, ensuring this component is an elementary condition;

- $\quad$ political interoperability provides the central power and support to achieve implementation and management of public administration interoperability. Here, we can differentiate both national and international dimensions.

The Interoperability Solutions for European Public Administrations (ISA) programme (2010-2015) [11] and its successor the ISA programme (2016-2020) [12] are the main instruments through which the current European interoperability strategy and European interoperability framework have been implemented. This has involved a variety of actions that aimed to improve digital collaboration between public administrations in Europe. The national interoperability framework observatory (NIFO) [8] measures progress and monitors the state-of-play of interoperability in the Union.

The Hungarian White Paper [1] is one of the outcomes of a 2015 Government Resolution [15], to set the groundwork for open data policies and activities. The document makes seven recommendations:

- $\quad$ Set higher open data targets than required by the EU;

- $\quad$ Actively encourage the use of open data, to create market opportunities and generate growth;

- $\quad$ Create a national data repository that can also host private sector open data;

- $\quad$ Make data available for free or at marginal cost;

- $\quad$ Create an organisation that specialises in the open data process;

- $\quad$ Consolidate the provision of data; and

- $\quad$ Start as soon as possible.

The documents also suggest that the government of Hungary should redouble its efforts to make public sector information available as open data, and actively help to create market opportunities. Recently Hungary began an overhaul of its Government Portal for Digital Services (Magyarorszag.hu), it is upgrading existing services and adding new ones [18]. The new portal aims to increase IT security and to make it easier for companies and citizens to access public services electronically.

\section{Public finance information systems in Hungary}

If we look for PFM IT solutions in Hungary from the perspective of interoperability, a series of information systems and online services can be found. These systems are operated by the State Treasury and other ministries providing digital solutions and online services in order to make public finance management more effective. 


\subsection{Public financial management (PFM) systems}

The PFM modernization process in Hungary started with a WBG operation in 1996. The project documentation shows that the main goal of the USD 7.7 million project was to reform the PFM system laying down the basis of TSA and establishing the Hungarian State Treasury (HST). The concept comprised a proposition on information centralisation to handle all public financial accounting transactions of the budget $[20,21]$. The envisioned concept is depicted by Figure 5 .
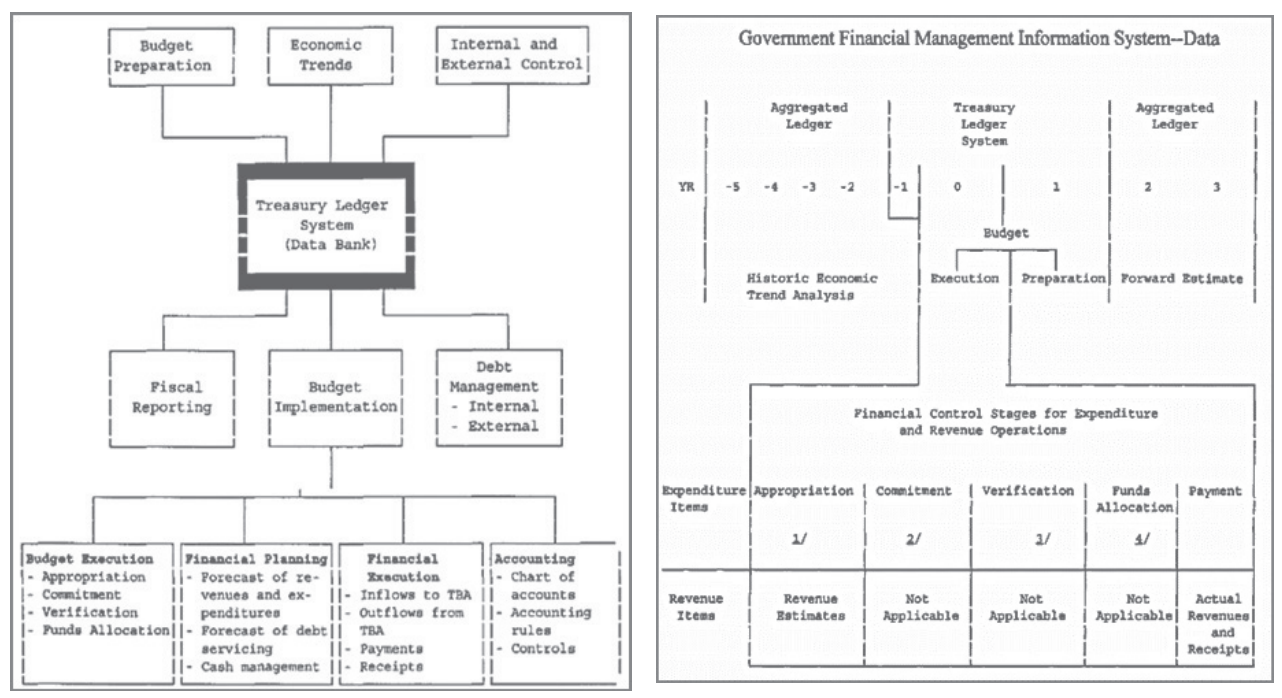

Figure 5: Vision drawn up by project documentation in 1996 for the Hungarian State Treasury [21]

In the middle of the 1990's the Hungarian State Treasury was set up by government resolutions (1128/1994. (XII.30.) and 2189/1995. (VII.4.) in order to realize the goals above and started its operations with a predominantly banking approach. Consecutively the State Audit Office carried out an audit that found that the budgetary planning phase was not adequately prepared compared to the complexity of control procedures, institutional workflows, and security requirements. Thus, - as the mentioned report says - the IT system created differed fundamentally from the immature system design.

In reality the evolution of PFM in Hungary yielded a very fragmented structure in the last two decades. The SPU accounting systems and the core treasury applications have been connected predominantly by the means of human interactions, although the level of ICT would enable to have a much more automatized scheme. Thus it is very expensive to provide human capacity to supervise data correctness as the number of transactions is increasing. Nonetheless supervision produces errors that can also be corrected by human intervention. Last but not least, working out consolidated data - that shows government performance on macroeconomic level - is also challenging with a diffuse system structure. The links among the HST systems are depicted by Figure 6. 


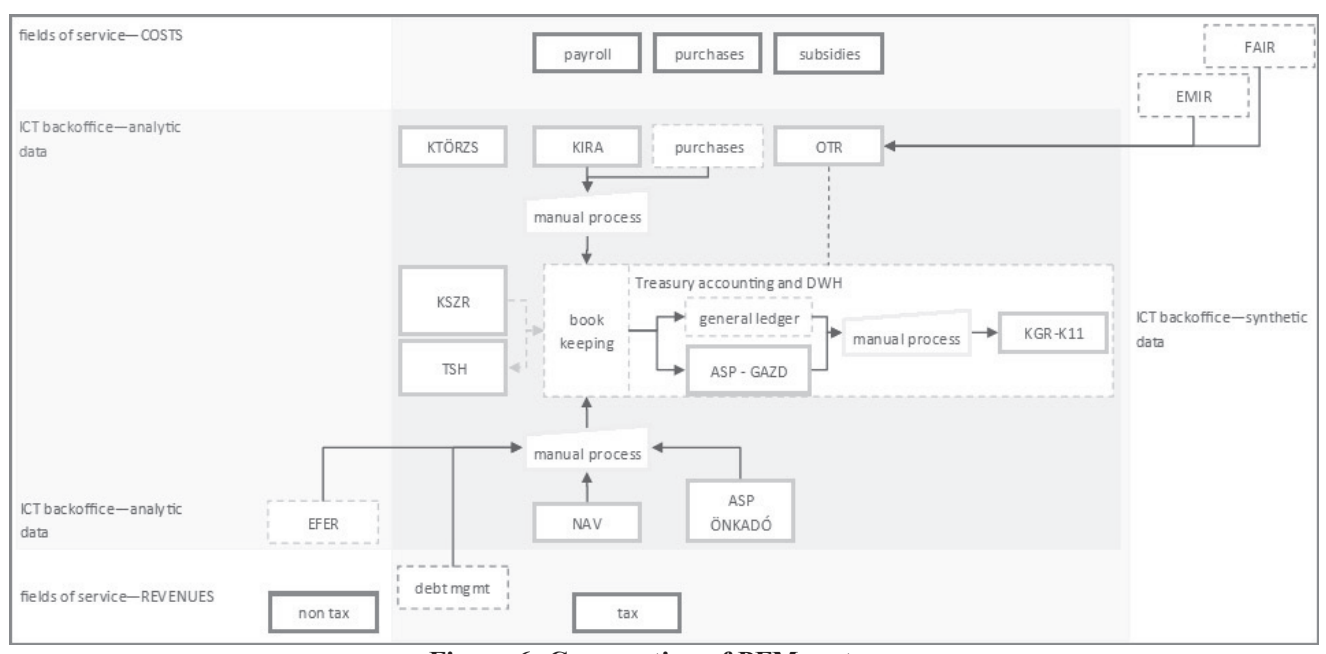

Figure 6: Cooperation of PFM systems

\subsubsection{K-Törzs}

One of the key elements of the budget execution is the so called K-TÖRZS, which consists of the master data of budgetary bodies not only in the central government but also on a local level. The data are published on the HST website and database is nominated as an authentic register by the law. This means that the data retrieved from in the database represent legal evidence. Besides real time data queries, historical data are also available on the website in order to have a traceable picture on the predecessors. Founding documents of budgetary organisations are published that comprise essential information on the activities, field of operation, leadership and main structure [19].

\subsubsection{KIRA}

The KIRA system centrally manages the payroll system for all public servants and general government employees. This means that ca. 900.000 people can get their monthly earnings by means of KIRA. The system is the primary information source for the accounting transactions of salaries and provides the basic documents for bookkeeping. Hence it is crucial for all stakeholders to keep the system up-to-date and to do the corrections needed on time.

KIRA strongly cooperates with the K-TÖRZS system mentioned above and produces output information for taxes paid by the single SPUs, payroll for the employees and naturally transfer data packages for the banking system. For some reasons the latter is not forwarded automatically but checked manually by SPUs [19].

\subsubsection{KSZR}

Payments of central government entities (and some other institutions forced to do so by law) are managed by the core banking system connected to Treasury System Account. Before the middle of the 90's this role was fulfilled directly by the Central Bank of Hungary but - in line with recommendations of the IMF and the WBG - the creation of TSA was a key motivation for the establishment of the Hungarian State Treasury in 1996. In the following years the task of management of public debt was transferred from HST to an agency which marked a clear borderline 
between the two institutions responsible for the liquidity management of the central budget. These days the core banking system of the Treasury consists of several subsystems where several interactions are made manually. Some of the budgetary controls are also provided by these systems that prevent the overspending of appropriation limits set by the budgetary law [19].

\subsubsection{TSH}

The main control element of the appropriation management system is the TSH. This component cannot be directly accessed by SPUs but they can reach it via some other information channels. Certain parts of the procedure are still paper-based, while other procedural elements are automatized via a form filling application. The cooperation of several system elements is strongly manually-backed while the everyday reconciliation with core banking system is automatized. The transactions of appropriations and financial flows are updated regularly and these data are taken (manually) to the reporting system [19].

\subsubsection{ASP}

For the municipalities the HST is developing a set of cooperating applications called ASP. These cover filing of documents, accounting, local taxation, property management, etc. as a standard service for the SPUs in their scope [19].

\subsubsection{KGR-K11}

All SPUs in Hungary are forced to hand in regular reports to the Hungarian State Treasury. Budgetary spending (special P/L statement) is reported monthly, balance sheets are provided quarterly and the submission of a yearly accounting report is also required. As the transactional level of accounting is not controlled centrally, the consistency check of these reports are made by the system itself during the submission of reports by means of complex pre-defined controls. According to latest developments, a ledger (backing the numbers of the specific report) is provided by the institutions in a standard format. (Earlier the consistency checks were done manually.) [19].

\subsubsection{OTR}

The Hungarian State Treasury is responsible to maintain a database on the data of subsidies provided by any budgetary institution. The system has a strong legal background since it is expressed in the law that those grant schemes and agreements are legally non-existent which are not registered in the OTR. According to these legal requirements all fund holders need to send the main decision making and contracting data via a specific interface to the OTR to check the double financing of the operations. Based on these checks, the OTR provides information on the results of checking through the above interface to fund holders. Besides the above functions, the OTR also supports the controls operated by the State Aid Monitoring Office according to rules set by the EU [19].

\subsection{Development policy database and information system (FAIR)}

Besides domestic development sources Hungary uses substantial amounts of EU funds to finance development projects. Additionally to the earlier mentioned PFM IT modules, the so called FAIR system has been established. The FAIR system serves for the collection of development policy data to create an extensive database on the implementation of different (European, national, other) 
development funds. The FAIR provides support for the complete development policy cycle. It is an integrated solution to plan, implement, measure and monitor different development programmes with specific procedures in a unified manner. The unified monitoring and management concept ensures comprehensive decision-making in the field of development policy. The FAIR system is depicted by Figure 7.

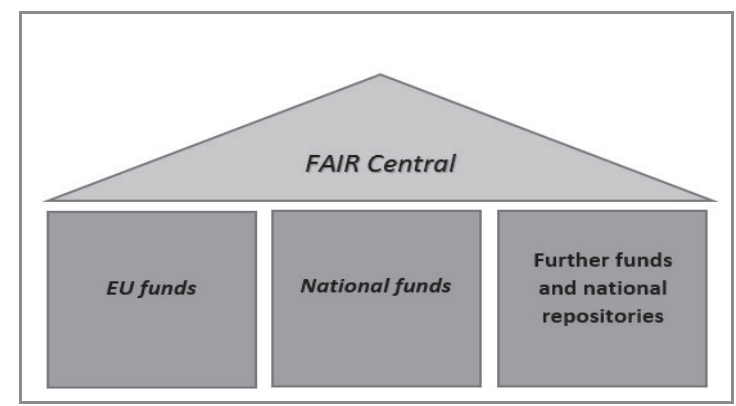

Figure 7: Schematics of the FAIR system

The FAIR realizes a unified monitoring and management concept via the connection of different specialized subsystems and data interfaces. The unified data structure of system components makes the monitoring data of different funds comparable and enables the unified measurement of programmes. The FAIR Central collects financial and physical monitoring data from other subsystems and data interfaces. The FAIR has specialized subsystems providing paperless fund management solutions for national and European funds. These management subsystems provide a specialized e-government portal for beneficiaries and online management modules for institutional users. These management systems are interoperable with the FAIR Central and transfer the relevant data automatically [14].

The scope of pertinent budgetary appropriations is defined by a specific government regulation on the central monitoring of funds. According to this regulation, funding institutions can use the above subsystems or develop their own management systems. In the latter case, the responsible institution needs to ensure that the in-house system collects all relevant data necessary for the unified monitoring concept. These data need to be periodically transferred into the FAIR via a statistical interface according to a pre-defined data format. Thus, external systems need to be interoperable with FAIR in order to ensure the compliance with the unified data structure. It can reasonably be assumed that interoperability plays a crucial role in ensuring data quality and the realization of a comprehensive monitoring concept.

The scope of necessary data is set out in the above regulation as two specialized data groups (one for financial instruments and one for non-refundable grants) taking into consideration the different types of funding. The set data scope covers the following: project data, data on project owners, data on the implementation and life cycle of projects (appraisal, decision-making, contracting, payments, progress reports, on the spot checks). These data (typically dates, financial and physical indicators and decision data) encompass the data structure of the unified monitoring concept [14].

As regards interoperability, the FAIR interfaces with several national data repositories (registry of budgetary organisations, company registry, civil registry) as well. These data connections enable funding authorities to retrieve valid data on project owners while checking the documents submitted by applicants and beneficiaries. By means of these functions data can be checked against authentic data sources without leaving the monitoring system. Certain data can be retrieved by project owners 
while completing administrative tasks in the e-government portal. In this manner certain data fields are auto-filled by the system, so the lead time of administrative tasks can be reduced. Since these data originate from state repositories, they do not necessarily need to be controlled by the funding authorities. In this way interoperability can significantly contribute to the reduction of administrative burdens [14].

\section{Future trends and opportunities in public financial data management}

The above examples highlight that to support a complex, modern PFM system several functions of the IT system are necessary and interoperability plays a significant role in the development and proper functioning of these PFM systems, and they show how the sharing of public data creates added value. However, there are further unused possibilities to improve the functioning of these systems and the utilization of the available data. It is reasonable to assume that interoperability and data sharing will remain a remarkable factor in the development of these IT systems in the long run. It is thus supposed that the analysis of the main drivers of interoperability may help in formulating assumptions on the future development trends and opportunities of this sector. The table below recapitulates the main information of the systems presented above.

\begin{tabular}{|c|c|c|c|}
\hline System & $\begin{array}{lll}\text { Main purpose } & \text { of } & \text { the } \\
\text { information system }\end{array}$ & Data scope & Main drivers of interoperability \\
\hline K-Törzs & Public database of budget entities & $\begin{array}{l}\text { Central and local government } \\
\text { bodies }\end{array}$ & Core master data for budgeting \\
\hline KIRA & Payroll system & All civil servants and employers & coherent data, effective employment \\
\hline KSZR & $\begin{array}{l}\text { Core banking system for SPUs } \\
\text { and other public bodies }\end{array}$ & $\begin{array}{l}\text { Payment management and } \\
\text { banking services }\end{array}$ & Liquidity management \\
\hline TSH & Database of appropriations & $\begin{array}{l}\text { Central budget spending } \\
\text { surveillance }\end{array}$ & Efficient budget execution \\
\hline ASP & $\begin{array}{l}\text { Group of applications for } \\
\text { municipalities covering key fields } \\
\text { of activity }\end{array}$ & $\begin{array}{l}\text { Municipalities' economic } \\
\text { activities }\end{array}$ & $\begin{array}{l}\text { Effective common IT background for } \\
\text { municipalities }\end{array}$ \\
\hline KGR-K11 & $\begin{array}{l}\text { Reporting on accounting data of } \\
\text { SPUs }\end{array}$ & Accounting data of all SPUs & $\begin{array}{l}\text { controlling, reporting to the } \\
\text { Parliament }\end{array}$ \\
\hline OTR & Monitoring system of subsidies & $\begin{array}{l}\text { Donations and subsidies made by } \\
\text { government bodies }\end{array}$ & Efficient allocation \\
\hline FAIR & $\begin{array}{l}\text { development policy decision } \\
\text { support, unified monitoring }\end{array}$ & $\begin{array}{l}\text { data on projects and project } \\
\text { owners, implementation data }\end{array}$ & $\begin{array}{l}\text { reduction of administrative burdens, } \\
\text { data quality }\end{array}$ \\
\hline
\end{tabular}

Table 1: Comparison of Hungarian public finance information systems

Comparing the main drivers of interoperability in case of PFM systems it can be assumed that several IT development projects were mainly focussed on the efficiency and effectiveness of budgetary procedures. The creation of a coherent data structure and a strong support for data analytics is another significant driver.

In the case of development policy, the utilization of interoperability and data sharing is twofold. First, they are utilized to reduce the administrative burdens of project owners and funding authorities. Second, the unified collection of relevant monitoring information improves data quality and facilitates more comprehensive policy decisions. The FAIR concept could be treated as a special example that could be realized in other policy sectors as well. Unified databases provide a better view on the progress and implementation of sectoral policy objectives. This requires a sectoral monitoring concept, the definition of shared data, and the development of a common database and the interoperability of all sectoral systems. From the perspective of other policy sectors, a unified sectoral database can be used for planning purposes, risk analysis and as a support for decision-making. 
Issues faced lead us back to basics: the formulation of the so called Treasury Ledger System (TLS as shown on Figure 6) is essential to gain proper, timely, coherent data framework in public financial accounting. An integrated PFM system should be based on a unified classification and regulatory environment in order to be sound, easily cumulated and comparable. The importance of these expectations were highlighted by the enormous effects of the sovereign debt crisis in 2008 . The Council of the European Union adopted a directive [9] with regard to the budgetary frameworks of the Member States and addressed the Commission to assess the suitability of IPSAS (International Public Sector Accounting Standards) for the Member States. ${ }^{4}$ The elaboration of this standard is being coordinated by EUROSTAT that studied the public accounting and auditing practices and the potential impact and sustainability of accrual accounting but its working group has not come to a conclusion yet.

The execution of the law on central government budget has a firm legislative background in Hungary. As from 2014 a new regulation entered into force that created a unique system of a combined budgetary (cash flow based) and financial (accrual) accounting, which is obligatory for all SPUs and other public sector entities. One of the main achievements was the unified chart of accounts and the detailed accounting standards set up by a government regulation ${ }^{5}$.

Unfortunately the everyday practice is more complex since the introduction of information systems was not controlled centrally and the SPUs use separately installed accounting systems deployed in line with the specific SPU needs. Consequently developments were not settled by unified methods and sometimes the diverging requirements may aggravate the establishment of interoperable database connections.

Hungarian State Treasury - that is also the body responsible for SPU reporting - made a survey on the usage of information systems by SPUs and the compliance with legislative changes.

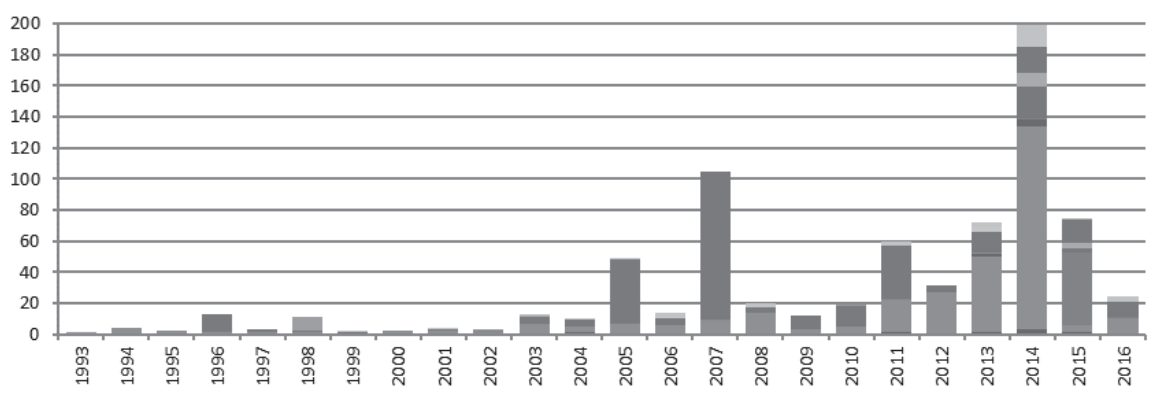

Figure 8: Year of implementation of accounting software currently in use

It was surprising that many of the 748 SPUs giving feedback did not choose to develop the current software but to change it to another, while no new supplier appeared on the market and all providers made the follow-up needed to comply with the new rules. The experiment was also interesting from the aspect of the timeliness of the developments because it took very much time to carry out the specification, procurement, development, etc. phases. Finally the following conclusions can be made:

\footnotetext{
${ }^{4}$ According to the latest updates his framework may be altered by the various interests of the different Member States

${ }^{5}$ As a reference to the survey of WBG cited above only the third of the countries apply a unified chart of accounts or accounting principles for all segments of budget execution [22].
} 
- Parallel development - given that every SPU has to follow the same accounting standards, classifications, and rules - hinders cost efficiency.

- Moderately coordinated developments result in heterogeneity in everyday accounting and the application of the law.

As information needs are rising and adequate IT solutions are available, PFM needs to be technologically renewed in Hungary. The interoperability of existent systems serve as a fundamental basis for a sound budget execution while a central database of transactional level information provides the opportunity to analyse deeper the transfers, cash flows and performance of government entities which is planned to go forward with the help of the planned MIS project of the Hungarian State Treasury.

This paper assumes that the identified drivers of interoperability will be present in the long term and the interconnected databases will further reduce burdens improve efficiency and data quality.

\section{Summary and conclusions}

Interoperability is becoming a key factor of our data based economy. The spread of information technology and the digitisation of business procedures increases the need for interconnected services thus interoperability might gain a significant ground in the future. The assumption that interoperability plays a critical role in the modernization of public services and the introduction of new digital solutions is also reflected by the development strategies of the European Union.

We have seen efforts in the last decades to establish multifunctional systems - also in the field of public financial management - but these projects show very wide-ranging results. The development of data management tools is dominated by the business sector, but public sector organizations often develop their own solutions since many business-oriented solutions cannot address the specificities of the public sector. Several government ICT tools were also developed for specific tasks as separate systems that also raised the need for cooperation between them. Thus huge efforts are made towards the improvement of connectivity of these systems but the level of interoperability shows great differences also within the same organization.

It is clear that interoperability is a determining factor to meet future integrated PFM system requirements. Nonetheless, it is important to emphasize that interoperability is not a pure technological concept it has a wide range of legal, political, organizational and semantic aspects. The experience show that without the harmonization of the processes and institutional needs, the applications and technical solutions are not properly used, which effects the effectiveness and efficiency of the whole system.

Meanwhile data protection rules further accelerate the free movement of data, but it also poses new challenges to IT development. These challenges result in a demanding and fastidious mission for professionals throughout government bodies. The process going on also in public finances and a roadmap is set in favour of providing the citizens with services of a higher and higher standard. Nevertheless in Hungary the case of development policy systems and the applied comprehensive approach poses a good model for future development. 


\section{References}

[1] ADVISORY BOARD OF THE NATIONAL COUNCIL FOR TELECOMMUNICATIONS AND INFORMATION TECHNOLOGY, White paper on Hungarian National Data Policy, (2016)

[2] DELOITTE, First steps into the labour market. Deloitte Central Europe. (2015)

[3] DENER, C., \& MIN, S. Y., Financial Management Information Systems and Open Budge Data - Do Governments Report on Where the Money Goes? Washington, DC: World Bank. (2013)

[4] DENER, C., WATKINS, J. A., \& DOROTINSKY, W. L., Financial Management Information Systems / 25 Years of World Bank Experience on What Works and What Doesn't. Washington D. C.: World Bank. (2011)

[5] EUROPEAN COMMISSION, COM 72 final, "Internet Policy and Governance - Europe's role in shaping the future of Internet Governance ", (2014)

[6] EUROPEAN COMMISSION, COM 178 final, "European Cloud Initiative - Building a competitive data and knowledge economy in Europe", 19.4. (2016)

[7] EUROPEAN COMMISSION, COM 134 final, "European Interoperability Framework Implementation Strategy ", (2017)

[8] EUROPEAN COMMISSION, National Interoperability Framework Observatory, Downloaded: 2018. 01, 30, Source: https://joinup.ec.europa.eu/collection/nationalinteroperability-framework-observatory-nifo?page $=1$

[9] COUNCIL OF THE EUROPEAN UNION, Directive 2011/85/EU of 8 November 2011 on requirements for budgetary frameworks of the Member States, (2011)

[10] EUROPEAN PARLIAMENT AND OF THE COUNCIL, Directive 2003/98/EC of 17 November 2003 on the re-use of public sector information, (2003)

[11] EUROPEAN PARLIAMENT AND OF THE COUNCIL, Decision No 922/2009/EC of September 2009 on interoperability solutions for European public administrations (ISA), (2009)

[12] EUROPEAN PARLIAMENT AND OF THE COUNCIL, Decision (EU) 2015/2240 of 25 November 2015, establishing a programme on interoperability solutions and common frameworks for European public administrations, businesses and citizens (ISA, programme) as a means of modernising the public sector, (2015)

[13] EUROPEAN PARLIAMENT AND OF THE COUNCIL, 679/2016/EU regulation, General Data Protection Regulation, (2016)

[14] GOVERNMENT OF HUNGARY, Regulation No. 60/2014, a támogatásból megvalósuló fejlesztések központi monitoringjáról és nyilvántartásáról, (2014) 
[15] GOVERNMENT OF HUNGARY, Resolution No. 1310/2015, a közadatok széles körü újrahasznosításához szükséges intézkedésekről, (2015)

[16] HASHIM, A., A handbook on financial management information systems for government: a practitioners guide for setting reform priorities, systems design, and implementation. Washington, D.C.: World Bank Group. (2014)

[17] INTERNATIONAL TELECOMMUNICATION UNION, Measuring the Information Society Report. Geneva, Switzerland: International Telecommunication Union. (2016)

[18] MAGYARORSZAG.HU, Új időszámítás az e-ügyintézésben, Downloaded: 2018.01.30., Source: https://hirkozpont.magyarorszag.hu/hirek/uj_idoszamitas_az_eugyintezesben.html

[19] MAGYAR ÁLLAMKINCSTÁR, Költségvetési információk, Downloaded: 2018.01.30., Source: $\quad$ http://www.allamkincstar.gov.hu/hu/koltsegvetesi-informaciok/koltsegvetesiinformaciok

[20] WORLD BANK GROUP, Projects of WBG, Downloaded: 2018.01.30., Source: http://www.worldbank.org/projects/search?lang=en\&searchTerm=\&themecode_exact=27

[21] WORLD BANK GROUP, Hungary - Public Finance Management Project (English) project Downloaded: 2018.01.30., Source: http://www.worldbank.org/projects/P043446/publicfinance-management-project?lang=en

[22] WORLD BANK GROUP, Public Financial Management Systems and eServices Global Dataset, Downloaded: 2017. 12 19., Source: http://data.worldbank.org/data-catalog/pfmsystems-eservices-dataset

[23] WORLD BANK GROUP, Public Financial Management Systems and eServices Global Dataset, Downloaded: 2018.01.30., Source: http://www.worldbank.org/en/topic/governance/brief/financialmanagement-information-systems-fmis 